\title{
Process engineering for pollution control and waste minimization
}

\author{
Mejdi Jeguirim $^{1} \cdot$ Lionel Limousy ${ }^{1}$
}

Received: 16 March 2017 / Accepted: 24 March 2017 / Published online: 5 April 2017

(C) Springer-Verlag Berlin Heidelberg 2017

The Biomass Energy, Environment and Sustainable Development workshop has been successfully organized in the frame of the International Renewable Energy Congress (IREC) conference which was organized in Hammamet (Tunisia) from March 22 to 24 2016. Approximately, 50 scientists joined the workshop to discuss the challenges of waste minimization and recovery, pollution analysis and treatment.

IREC covers a wide range of topics concerning renewable energies from solar thermal energy to biomass energy and others. During this congress different scopes are approached such as materials and technologies, modelling and simulation, optimization, energy efficiency, sustainability... The seventh edition of IREC offered the possibility to organize a workshop dedicated to the chemical engineering community, which works specifically on applications for biomass treatment, transformation and valorisation. This event offers the possibility to build new collaborations between foreign research teams but also benefit from a convenient environment to welcome researchers. The workshop mostly focused on two research fields: water treatment and energy production from biomass.

Protection of environment as well as the energetic valorisation of biomass resources has become crucial since more than 20 years. The world faces to a complex situation with the emergence of developing countries, which lead to an increase of fossil fuel demand, to an acceleration of feedstock

Responsible editor: Philippe Garrigues

Mejdi Jeguirim

mejdi.jeguirim@uha.fr

Lionel Limousy

lionel.limousy@uha.fr

1 Institut de Science des Matériaux de Mulhouse, 15 Rue Jean Starcky, 68057 Mulhouse, France consumption and to the generation of large amount of wastes and pollutions. The latter has led to a lot of researches, in order to minimize the impact of wastes and pollutants on the environment. Among the different processes which are used to remove pollutant from wastewater, adsorption is one of the more studied. To reach high pollutant abatement without a prohibitive cost, new cheap materials were developed these last years mainly from biomass and waste solids. Biomass may origin from different sources: sawmill industry, agriculture, agro-industry... Depending on its origin, biomass composition may be different in composition and in structure. Raw biomass can be used as biosorbent, but generally, a thermal treatment is applied (torrefaction, pyrolysis) in order to increase the surface area and the porosity of the biomass, offering higher adsorption capacities for organic and mineral compounds. At this stage, the adsorbent is called biochar. To obtain higher adsorption properties and to obtain sorbents with high selectivity, biochars can be activated by chemical or physical routes. The activated carbons present important surface areas (sometimes more than $2000 \mathrm{~m}^{2} / \mathrm{g}$ ) and their porosities can be designed depending on the final application (micro and/or mesoporosity). These materials are often used for the removal of organic pollutants present in wastewater at low concentration, as it is described in several papers of the special issue. Water treatment can be also investigated by filtration process. Depending on the nature of the compounds present in the feed solution (organics, salts, bacteria, particles), the process has to be adapted in order to reach the best performance with high durability. The main problem which is encountered when using filtration membranes corresponds to fouling due to the adsorption of molecules and bacteria at the surface of the filtration layer. Different treatments have to be applied to recover good performances of the membranes, they are at the origin of additional costs (chemical reagents, process stop, etc.) and environmental impacts. These aspects 
were also discussed during the seventh edition of IREC, and two papers are published in this special issue.

The energetic approach relative to biomass valorisation may be broad. In fact, among the various systems and process developed for the production of energy from biomass, we can differ two approaches: direct or indirect valorisation. The direct valorisation mainly focuses on the development of new conversion process and their optimisation, while indirect valorisation leads to the transformation of biomass (thermal, chemical, physical) to optimise the energy balance, to extract valuable compounds and produce different fuels, or to remove water and pollutants. These different aspects were presented during the workshop; they corresponded to half of the scientific presentations.

Twenty-five papers have been selected for this special issue, and after being peer-reviewed, 17 accepted for publication covering important subjects of process engineering. Eight papers focus on energy and biofuel production through various thermochemical and biochemical processes. The next nine papers correspond to wastewater and potable water treatment using different techniques such as adsorption, anodic oxidation and membrane filtration. Here is a short description of the different works that have been accepted in this special issue.

Azzaz et al. (2017) investigated the alkaline modification of raw orange tree sawdust for improving the adsorption of methylene blue (MB) dye from synthetic solutions. This work was performed in batch reactor; the optimization of the process was done from the response surface methodology approach (RSM). Different characterizations were performed to observe the modification of the biomass as well as the interaction of MB with the modified biomass.

Blel et al. (2017) have studied the antimicrobial and the antifouling of different oxide materials mainly used for filtration applications. Experimental tests were carried out using two different setups: a shear stress module for the study of bacteria adhesion on plate surfaces, and an ultrafiltration device for the study of membrane fouling. The authors observed a modification of the membrane fouling when using copper-exchanged zeolite as filtration layer.

Borrero-López et al. (2017) have worked on the valorization of olive stones by hydrothermal carbonisation. They have both studied the production of furfural and 5-methylhydroxyfurfural products, and the properties of hydrochars. These last were carbonized at $900{ }^{\circ} \mathrm{C}$ to produce a highly ultramicroporous biochar.

Chaabane et al. (2017) investigate the treatment of grey water by filtration with an upflow-downflow siliceous sand/marble waste filtration system. The objective was to treat the grey water for agricultural and industrial purposes.

Djelal et al. (2017) have identified a strain isolated from dates, which is able to enhance high gravity ethanol production.
The fermentation of glucose, sucrose and fructose was performed in batch reactor, and promising results were obtained both for ethanol production and also for the tolerance of strain to high sugar concentration.

Ghazouani et al. (2017) have developed new research on the electrochemical treatment of different kind of wastewater effluents. BOD electrode was used to perform the experiments. The effectiveness of the electrochemical treatment was assessed by nitrogenous compounds and COD removals.

Homsi et al. (2017) have tested the performances of different catalysts for ethanol steam-reforming reaction. Catalysts were prepared by wet impregnation. The deactivation of the different catalyst due to the formation of high amounts of carbonaceous products was also investigated.

Issaoui et al. (2017) have prepared low-cost tubular macroporous support for ceramic membranes. These membranes were obtained by mixing sand, kaolin and starch, followed by a thermal treatment. Textural, structural and physical properties of the different materials were done. The filtration of solutions containing microalgae was performed.

Jeguirim et al. (2017) have worked on the identification of correlations between the mineral contents in agropellets and particle matter and bottom ash characteristics during combustion in domestic boilers. Analytical methods were used to characterize the minerals contained in particles, and chemometric analysis was conducted to find correlation between the mineral contents and PM and bottom ash characteristics.

Kesraoui et al. (2017) have studied the potential of electrochemical process for the removal of indigo carmine dye. The main objective was to study the effect of an alternating current (AC) on the adsorption process. Results showed that the adsorption kinetics was strongly improved in the presence of AC.

Kraiem et al. (2017) have explored the disposal of waste frying oil. Pyrolysis was used to treat the liquid waste in order to improve the quality of the produced bio-oil. The physical and thermal characteristics of the bio-oil were analysed; results showed that the biofuel presented interesting properties but several investigations have to be done to improve its quality.

Labaki and Jeguirim (2017) have presented a review article on the thermochemical conversion of waste tyres. The different routes for energy recovery are presented in this article: pyrolysis, gasification and combustion. The effects of different parameters as well as kinetics of the different process are summarized in the review article.

Limousy et al. (2017) have studied the adsorption of amoxicillin on an activated carbon obtained by chemical activation of olive stone biochar. The microporous adsorbent was characterized by several techniques and adsorption was modelled in 
order to understand the nature of the interactions between the $\mathrm{AC}$ and amoxicillin.

Masson et al. (2017) have worked on the adsorption of seven micropollutants on activated carbon. The physical parameters of adsorption were studied using micro-calorimetry, Van't Hoff method and COSMO-RS simulations. The main role of Van der Waals forces in the adsorption process was shown.

Ribeiro et al. (2017) have compared the combustion of three different residual forest biomasses (RFB) in a bubbling fluidized bed pilot. Ash and particles were collected at different locations of the experimental setup to be analysed. The compositions of fly and bottom ashes were different considering the three forest biomasses.

Tamošiūnas et al. (2017) have investigated the valorisation of glycerol by utilizing thermal water vapour plasma. The production of syngas was followed for crude and a pure glycerol to compare the concentrations of the formed product gas.

Wanassi et al. (2017) have recycled cotton waste coming from textile industry to produce an activated carbon. A chemical activation mode was used with zinc chloride. The adsorption of alizarin $\mathrm{S}$ dye was studied. Textural, structural and chemical analyses of the AC were performed; adsorption isotherms were modelled by Langmuir-Freunlich and Sips models.

The Guest Editors of this special issue are thankful to the Editor-in-Chief of Environmental Science and Pollution Research, Professor Philippe Garrigues, for providing an opportunity to publish selected peer-reviewed papers that were presented at the $\mathrm{BE}^{2} \mathrm{SD}$ workshop. Thanks are also to the Editorial Assistants of the journal, Mrs. Marianne Salaün and Mrs. Géraldine Billerot for their great support and patience at every stage in the preparation of the issue. Recognitions are also to the entire production team of the journal for their valuable support in bringing out this issue. Last but not least, our sincere appreciation to all the reviewers for their invaluable and critical review comments on manuscripts that were submitted for this special issue.

\section{References}

Azzaz AA, Jellali S, Akrout H, Assadi AA, Bousselmi L (2017) Optimization of a cationic dye removal by a chemically modified agriculture by-product using response surface methodology: biomasses characterization and adsorption properties. Environ Sci Pollut Res. doi:10.1007/s11356-016-7698-6

Blel W, Limousy L, Dutournié P, Ponche A, Boucher A, Le Fellic M (2017) Study of the antimicrobial and antifouling properties of different oxide surfaces. Environ Sci Pollut Res. doi:10.1007/s11356016-7762-2

Borrero-López AM, Fierro V, Jeder A, Ouederni A, Masson E, Celzard A (2017) High added-value products from the hydrothermal carbonisation of olive stones. Environ Sci Pollut Res. doi:10.1007/ s11356-016-7807-6

Chaabane S, Riahi K, Hamrouni H, Ben Thayer B (2017) Suitability assessment of hydrochemical grey water quality treated with an upflow-downflow siliceous sand/marble wastes filtration system for agricultural and industrial purposes. Environ Sci Pollut Res. doi:10.1007/s11356-016-7471-x

Djelal H, Chniti S, Jemni M, Weill A, Sayed W, Amrane A (2017) Identification of strain isolated from dates (Phœnix dactylifera L.) for enhancing very high gravity ethanol production. Environ Sci Pollut Res. doi:10.1007/s11356-016-8018-x

Ghazouani M, Akrout H, Bousselmi L (2017) Nitrate and carbon matter removals from real effluents using Si/BDD electrode. Environ Sci Pollut Res. doi:10.1007/s11356-016-7563-7

Homsi D, Abou Rached J, Aouad S, Gennequin C, Dahdah E, Estephane J, Tidahy HL, Aboukaïs A, Abi-Aad E (2017) Steam reforming of ethanol for hydrogen production over $\mathrm{Cu} / \mathrm{Co}-\mathrm{Mg}$-Al-based catalysts prepared by hydrotalcite route. Environ Sci Pollut Res. doi:10.1007/ s11356-016-7480-9

Issaoui M, Limousy L, Lebeau B, Bouaziz J, Fourati M (2017) Manufacture and optimization of low cost tubular ceramic supports for membrane filtration: application to algal solution concentration. Environ Sci Pollut Res. doi:10.1007/s11356-016-8285-6

Jeguirim M, Kraiem N, Lajili M, Guizani C, Zorpas A, Leva Y, Michelin L, Josien L, Limousy L (2017) The relationship between mineral contents, particle matter and bottom ash distribution during pellets combustion: molar balance and chemometric analysis. Environ Sci Pollut Res. doi:10.1007/s11356-017-8781-3

Kesraoui A, Selmi T, Seffen M, Brouer F (2017) Influence of alternating current on the adsorption of indigo carmine. Environ Sci Pollut Res. doi:10.1007/s11356-016-7201-4

Kraiem T, Ben Hassen A, Belayouni H, Jeguirim M (2017) Production and characterization of bio-oil from the pyrolysis of waste frying oil. Environ Sci Pollut Res. doi:10.1007/s11356-016-7704-Z

Labaki M, Jeguirim M (2017) Thermochemical conversion of waste tyres - a review. Environ Sci Pollut Res. doi:10.1007/s11356-016$7780-0$

Limousy L, Ghouma I, Ouederni A, Jeguirim M (2017) Amoxicillin removal from aqueous solution using activated carbon prepared by chemical activation of olive stone. Environ Sci Pollut Res. doi:10. 1007/s11356-016-7404-8

Masson S, Vaulot C, Reinert L, Guittonneau S, Gadiou R, Duclaux L (2017) Thermodynamic study of seven micropollutants adsorption onto an activated carbon cloth: Van t Hoff method, calorimetry and COSMO-RS simulations. Environ Sci Pollut Res. doi:10.1007/ s11356-016-7614-0

Ribeiro JP, Vicente ED, Alves C, Querol X, Amato F, Tarelho LAC (2017) Characteristics of ash and particle emissions during bubbling fluidised bed combustion of three types of residual forest biomass. Environ Sci Pollut Res. doi:10.1007/s11356-016-8099-6

Tamošiūnas A, Valatkevičius P, Gimžauskaite D, Jeguirim M, Měčius V, Aikas M (2017) Energy recovery from waste glycerol by utilizing thermal water vapor plasma. Environ Sci Pollut Res. doi:10.1007/ s11356-016-8097-8

Wanassi B, Ben Hariz I, Ghimbeu CM, Vaulot C, Ben Hassen M, Jeguirim M (2017) Carbonaceous adsorbents derived from textile cotton waste for the removal of alizarin $\mathrm{S}$ dye from aqueous effluent: kinetic, thermodynamic and equilibrium studies. Environ Sci Pollut Res. doi:10.1007/s11356-017-8410-1 


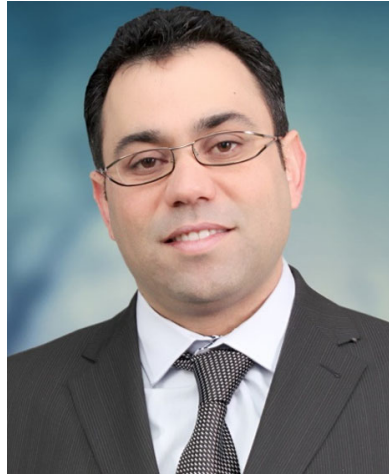

Dr. Mejdi Jeguirim is an associate professor at the University of Haute Alsace (France) since 2005 in the field of energy and process engineering. He dedicates most of his career to the biomass valorization through thermochemical conversion and the elaboration of chars with controlled porosity devoted to the treatment of aqueous and gaseous effluents. These research topics were performed in the frame of several international collaborations (Tunisia, Germany, Belgium, Algeria, Lebanon, Greece, Turkey, Cyprus, etc.) and industrial contracts. He acted as $\mathrm{PhD}$ advisor for 10 students and he has co-authored more than 70 referred international journal papers in his research field. He is a member of the editorial boards of international scientific journals (Energy for Sustainable development, Energy, Energies) and belongs to the scientific committee of several international congresses (IREC, EMR, ICSSWM, etc.). He is involved as a scientific expert for more than 40 international scientific journals as well as for several national and international research programs (French ANR, Mines Carnot, Research Ministry of Romania, Research Ministry of Kazakhstan). He is the financial and administrative manager of the Energy and HVAC Professional Degree, Specialty: Renewable Energy and Sustainable Development at the Faculty of Science and Technology of Mulhouse. He has received the French National Research Excellence Award for researcher with high level scientific activity for the 2009-2012 and 2013-2016 periods.

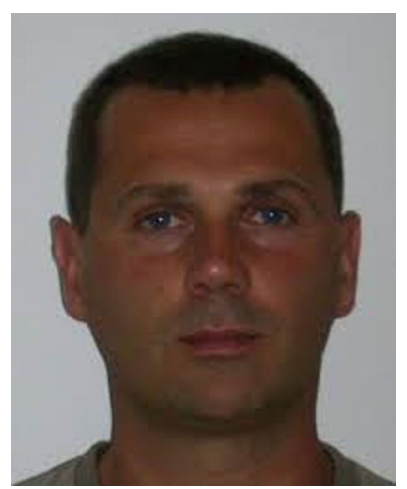

Dr. Lionel Limousy is an associate professor in the Environmental Engineering and Sustainable Development department at the University of Haute Alsace (France) since 2010. He teaches in the field of chemical and environmental engineering, and also in the field of risk management and assessment. He was recruited in 2000 at the University of South Brittany as an associate professor. He was in charge on the Chemical Engineering and Process department from 2003 and 2005. Then, he created the Prodiabio platform in 2005 and he was the director of this institution until 2010. In 2013, he joined the Institute of Material Science of Mulhouse where he became responsible of the industrial research partnership. He has experience in different research fields: biological and chemical treatment of wastewater, membrane filtration, biomass valorisation and material characterisation. $\mathrm{He}$ is involved in several academic and industrial (national or international) scientific projects. He has collaborated in the organising of several International Congress (ICEC, IREC, EMR, etc.), of several special issues in different journals (Comptes rendus de Chimie, International Journal of Chemical Reactor Engineering, Energies, etc.) and he has approximately 60 peer-reviewed scientific publications, 2 book chapters and 2 patents. He has received the French National Research Excellence Award for researcher with high level scientific activity for the 20132016 and $2017-2020$ periods. 